\title{
The Relationship between Budget Adequacy and Student Enrolment in TVET Institutions in Bungoma County, Kenya
}

\author{
Jayne Nasimiyu Wasike $^{1^{*}}$, Dr. Juma Ingendi ${ }^{2}$, Prof Julius Maiyo ${ }^{3}$ \\ ${ }^{1}$ Department of Education, Foundations, Planning and Management, Kibabii University, P.O. Box 1699-50200, Bungoma, Kenya \\ ${ }^{2}$ Department of Educational Foundations, Masinde Muliro University of Science and Technology, P.O. Box 190-50205, Kakamega, Kenya \\ ${ }^{3}$ Department of Education, Planning and Management, Kibabii University, P.O. Box 1699-50200, Bungoma, Kenya
}

\begin{abstract}
DOI: $10.36348 /$ jaep.2020.v04i09.003 $\quad$ | Received: 03.09.2020 | Accepted: 10.09 .2020 | Published: 30.09 .2020
*Corresponding author: Jayne Nasimiyu Wasike
\end{abstract}

\section{Abstract}

The purpose of the study was to investigate the relationship between budget adequacy and student enrolment in TVET institutions in Bungoma County, in Kenya. Proportionate stratified sampling, Census and simple random sampling were used to select a sample size of 426 respondents. Data was collected using questionnaires and document analysis. The items from the main questionnaire were organised according to the specific research objectives. Data was analyzed was done using descriptive statistics, Pearson correlation and Linear regression. The study established that budget adequacy has a statistically significant relationship with student enrolment and recommended that government and other relevant stakeholders make adequate budget allocation to TVET institutions for institutional resource in order to increase student enrolment .Additionally TVET institutions should be empowered to engage in income generating activities without losing focus on their core mandate.

Keywords: Budget Adequacy, Institutional resources, Student Enrolment.

Copyright @ 2020: This is an open-access article distributed under the terms of the Creative Commons Attribution license which permits unrestricted use, distribution, and reproduction in any medium for non-commercial use (NonCommercial, or CC-BY-NC) provided the original author and sources are credited.

\section{INTRODUCTION}

TVET is regarded as a key lever of international economic development, social advancement and by extension a panacea to the ever rising challenge of youth unemployment [1]. To this end governments the world over have not spared financial and planning resources with the aim of increasing student enrolment in TVET institutions [2]. However, student enrolment in TVET Institutions continues to be low. This can be partly attributed to inadequate budgetary allocation for institutional resource development which includes infrastructure, teaching learning equipment and adequate qualified human resource [3].

A study done by Kipyego [4] investigated government subsidies and their influence on student access and retention in secondary schools in Nandi Sub County, Kenya. A descriptive survey design was used in this study. The sample size was 358 students, proportionate and simple random sampling techniques were used. Questionnaires and interview schedules were used in data collection. Data was analyzed using quantitative and qualitative techniques. Frequencies, percentages and Pearson correlation were used to analyze quantitative data. The study findings showed that late disbursement of funds by government agencies affected student enrolment.

In another study, Anyanua \& Erhijakpor [5] explored government expenditure and student enrolment in a selected African countries; Egypt, Algeria, Nigeria and South Africa. The findings indicated that government expenditure on education has a positive impact on enrolment.

Mutiso et al., [6] investigated the impact of sources of funds on access to superior higher education in Kenyan public universities. Data was taken from 446 respondents comprised of university senior managers, 36 department heads and 400 undergraduate students. The education production function was employed a basic model of the research. The findings of the study showed that government capitalization, tuition, and other money sources were found to be of significant importance for accessing quality education in the Kenyan public universities $(\mathrm{P}=0.30, \mathrm{P}=0.018, \mathrm{P}=0.000)$.

Rabia et al., [7] carried out a gender analysis of the public sector educational financing in Pakistan. Through a gender lens, the researcher examined 
budgetary allocations and spending at Federal and Provincial levels from pre-primary to secondary level education for the period of 2016 -2018. The research approach used four instruments including the revision of key informants, meetings with stakeholders and thorough analysis of budgetary procedures, as well as current secondary information and data. The study found gender disparities in primary school graduates. According to the report, 47 per cent boys were dropouts in the Punjab as compared to 58 per cent girls in Sindh while 39 per cent boys were drop-outs in the Punjab as compared to 41 per cent girls. The report also established significant gender differences in expenditure allocations. The study recommended reconfiguration of the budget making process to ensure adequate funding for the girl child education right from the initial stage.

Sarkar et al., [8] evaluated both the distribution of income and development budgets for education in Bangladesh and compared with other countries in South Asia, with particular focus on higher education. It is observed that an inadequate education budget in Bangladesh was affecting the expansion of higher education and the index of human growth. Two main problems were mismanagement of funds and noncompliance with guidelines for budget implementation for higher education. In addition to having sufficient government budget support, public universities could engage in income generating activities within and without the university.

Mutegi [9] carried out a study on the influence of unit cost of education on student enrolment rates in public secondary schools in Tharaka South Sub-County in Kenya. The study used Correlational research design to establish the relationship between unit cost of education and students' enrolment rates in public secondary schools. The data was collected from household heads and principals of secondary schools and also from Ministry of Education officers. The target population comprised all the 23,275 household heads and 26 principals. The Yamane's formula was used to get a sample of 393 household heads while census was used to get the number of school principals who participated in the study. The questionnaires, interview schedule and education document analysis were the main data sources. The study established that government education subsidies promoted increased enrolment in secondary schools.

The effect of tuition fees on the University Registration and location decisions of secondary school graduates in Germany was studied by Alecke et al., [1]. In 2005,7 out of 16 German federal states adopted tuition fees for higher education, following a Federal Constitutional Court ruling. In the empirical study, they used the variation over time and across regions to isolate the causal effect of tuition fees on student enrolment and migration. The findings showed that tuition fees generally did not impact internal enrolment rates.

Hemelt \& Marcotte [10] analyzed tuition increases and the expected impacts of enrolment in the United States. Data from 1991 to 2006 on all U.S. 4year public colleges and universities was used to show that teaching/ learning began significantly early in this decade. They analyzed the impact on total registration and credit hours of these increases and projected differences by type of institution. The average tuition and fee elasticity of the total headcount was estimated to be an average of -0.0958 , with tuition fees and an increase of $\$ 100$ leading to a decrease in enrolment by $0.25 \%$

Ivo \& Prasetyia [11] examined factors that drive expenditures on basic education in Indonesian districts. Panel-data set covering 398 districts between 2005 and 2012 was used. The objective was to establish the impact of socio-economic, political and geographical factors on expenditures per pupil and on the overall budget spent on education. The results of the study concurred with results of other countries showing an increase in educational expenditures in the municipalities' fiscal capacity. The findings also concur with the fact that an increase in the educational budget results in an increase in the demand for education.

Ali et al., [12] carried out a study to determine the relationship between public expenditure for TVET and employability skills of the graduates of vocational colleges in Malaysia. The methodology was crosssectional research design which permitted the researcher to integrate public expenditure for education literature review and questionnaires to collect data. The study was conducted at an agricultural vocational college in Peninsular Malaysia using convenient sampling technique and sample size of 138. Data analysis used the SmartPLS path model analysis. The findings from the study showed that recurrent expenditure was significantly correlated with employability skills and development expenditure was significantly correlated with employability skills. In conclusion, TVET administrators' ability to provide and manage financial resources leads to enhanced graduate's employability skills.

The literature reviewed revealed that numerous studies in budget adequacy and student enrolment in TVET institutions have been carried out. Some of these include; Kipyego [4], Rabia et al.,[7], Alecke et al., [13], Anyanua \& Erhijakpor [5], Ali et al., [12] and Ivo \& Prasetyia [11]. However the studies did not specifically address the relationship between budget adequacy and student enrolment. Additionally the approaches, research design, methodology, sampling techniques and sample sizes, study areas and locations were different and borrowed concepts from each other. The current study sought to fill the gap in literature by 
specifically addressing the relationship between budget adequacy and student enrolment in TVET institutions.

\section{RESEARCH METHODOLOGY}

Correlational research design was the most suitable for the study to test the hypothesis and establish the relationship between the variables. Questionnaires and document analysis were used to collect data. Proportionate stratified, simple random sampling and census were employed for the study. From a target population of 9885 , a sample size of 426 respondents was obtained. Proportionate stratified random sampling was used to select 65 TVET institutions from the 82 in the 9 sub-counties in Bungoma County. 65 principals of the sampled TVET institutions were selected by Census and simple random sampling was used to select 2 lecturers from the sampled TVET institutions giving a sample size of 130 lecturers and 3 students from 61 VTCs and 12 from 4(3TTIs and 1 IST), because the TTIs and IST had a higher student enrolment, giving a total of 231 TVET students. As shown in Table 1.

Table-1: Sample sizes of TVET institutions and respondents in Bungoma according to Sub Counties

\begin{tabular}{|l|l|l|l|l|l|l|l|}
\hline \multirow{2}{*}{ Sub county } & \multicolumn{3}{|l|}{ Institutions/Sub County } & \multicolumn{2}{l|}{$\begin{array}{l}\text { Sample size of TVET institutions } \\
\text { \& respondents }\end{array}$} \\
\cline { 2 - 9 } & $\begin{array}{l}\text { TTIs \& } \\
\text { IST }\end{array}$ & VTCs & $\begin{array}{l}\text { Total } \\
\text { TVETs }\end{array}$ & $\begin{array}{l}\text { Sampled } \\
\text { TVETs }\end{array}$ & $\begin{array}{l}\text { TVET } \\
\text { students }\end{array}$ & $\begin{array}{l}\text { TVET } \\
\text { Lecturers }\end{array}$ & $\begin{array}{l}\text { TVET } \\
\text { Principals }\end{array}$ \\
\hline Kimilili & 1 & 9 & 10 & 8 & 33 & 16 & 8 \\
\hline Mt. Elgon & & 8 & 8 & 6 & 18 & 12 & 6 \\
\hline Bungoma Central & 1 & 7 & 8 & 6 & 27 & 12 & 6 \\
\hline Bungoma West & - & 8 & 8 & 6 & 18 & 12 & 6 \\
\hline Bungoma South & 1 & 11 & 12 & 10 & 39 & 20 & 10 \\
\hline Bumula & 1 & 14 & 15 & 12 & 45 & 26 & 12 \\
\hline Bungoma North & - & 10 & 10 & 8 & 24 & 16 & 8 \\
\hline Webuye East & - & 4 & 4 & 3 & 9 & 6 & 3 \\
\hline Webuye West & - & 7 & 7 & 6 & 18 & 10 & 6 \\
\hline Total & $\mathbf{4}$ & $\mathbf{7 8}$ & $\mathbf{8 2}$ & $\mathbf{6 5}$ & $\mathbf{2 3 1}$ & $\mathbf{1 3 0}$ & $\mathbf{6 5}$ \\
\hline
\end{tabular}

\section{RESULTS FINDINGS AND DISCUSSION}

The following null hypothesis was tested:

$\mathbf{H}_{\mathbf{0}}$ : Budget adequacy has no significant relationship with student enrolment in TVET institutions in Bungoma County.

\section{Relationship between Budget Adequacy and Student Enrolment in TVET Institutions}

The objective of the study sought to investigate the relationship between budget adequacy and student enrolment in TVET institutions in Bungoma County. Budget adequacy was measured in terms of level of institutional resource development, sources of funding and perception of adequacy of funding using a multi- item Likert scale. To achieve the objective the following hypothesis was tested; $\mathbf{H}_{\mathbf{0}}$
Budget adequacy has no significant relationship with student enrolment in TVET institutions in Bungoma County.

\section{Descriptive Statistics on Budget Adequacy}

To determine if budget adequacy had a relationship with student enrolment; respondents were asked to rate on a 5-point multi-item Likert scale based on given statements. Data was gathered from principals on the level of institutional resource development in order to determine budget adequacy in terms of whether the level of institutional resource development had an influence on the level of student enrolment.

The responses of the Principals on the level of Institutional resource development are shown in table 2.

Table-2: Level of institutional resource development and student enrolment

\begin{tabular}{|l|l|l|l|l|l|l|l|}
\hline S/N & Resource development & SD & D & N & A & SA & MEAN \\
\hline a. & Enough classrooms & 2 & 7 & 5 & 22 & 19 & 3.89 \\
\hline b. & Enough workshops & 13 & 16 & 11 & 12 & 3 & 2.56 \\
\hline c. & Enough laboratories & 17 & 18 & 10 & 10 & 0 & 2.24 \\
\hline d. & Enough Provision of other infrastructure & 23 & 29 & 2 & 1 & 0 & 1.65 \\
\hline e. & Provision of adequate teaching learning equipment & 10 & 22 & 13 & 10 & 0 & 2.42 \\
\hline g. & Enough qualified instructors /teachers & 19 & 7 & 14 & 13 & 2 & 2.49 \\
\hline h & Opportunities for capacity building initiatives for staff & 9 & 11 & 18 & 7 & 10 & 2.96 \\
\hline
\end{tabular}


Table 2 shows the response to the question whether the TVET institutions had adequate classes, 41 respondents representing74.5\%agreed (4 and 5 on the scale), $5(9.1 \%)$ were indifferent while the remaining 9 respondents representing $16.4 \%$ disagreed ( 1 and 2 on the scale). With a mean score of 3.89 , the study results indicate that the TVET institutions had adequate classrooms.

On whether the TVET institutions had enough workshops 15 respondents representing $27.3 \%$ agreed (4 and 5 on the scale), $11(20.0 \%)$ were indifferent while the remaining 29 respondents representing $52.7 \%$ disagreed (1 and 2 on the scale). The mean score of 2.56 indicates that the respondents were on average indifferent but since there were more respondents who disagreed than those who agreed, the study results indicate that the workshops in TVET institutions were not adequate.

As for whether they had enough laboratories, 10 respondents representing $18.2 \%$ agreed (4 and 5 on the scale), $10(18.2 \%)$ were indifferent while the remaining 35 respondents representing $63.6 \%$ disagreed ( 1 and 2 on the scale). The mean score of 2.24 indicates that the respondents on average disagreed that laboratories in TVET institutions were adequate.
The mean values of $1.65,2.42$ and 2.49 for there being enough provisions for other infrastructure, adequate teaching/ learning equipment and enough qualified instructors /teachers respectively indicate that the respondents disagreed hence indicating that majority of the TVET institutions in Bungoma County do not have financial provisions for extra infrastructural developments just as they have no adequate funds for the acquisition of teaching /learning resources. Likewise, they do not have adequate qualified staff hence may not be able to meet the needs of the students in terms of knowledge acquisition.

On whether the institutions have opportunities for capacity building initiatives for staff 17 respondents representing $30.9 \%$ agreed (4 and 5 on the scale), 18 $(32.7 \%)$ were indifferent while the remaining 20 respondents representing $36.4 \%$ disagreed (1 and 2 on the scale). The results indicate that majority of the TVET institutions surveyed were not adequately equipped and this has led to low student enrolment hence the need for more funding.

\section{Source of funding for the TVET institutions and student enrolment}

The respondents were requested to indicate whether they do receive funding from the stated agencies and their responses are as presented in table 3 .

Table-3: Source of Funding for TVET Institutions and student enrolment

\begin{tabular}{|l|l|l|}
\hline Source of Funding & Frequency & Percent \\
\hline Constituency bursary fund & 41 & $74.5 \%$ \\
\hline National government bursary fund & 55 & $100 \%$ \\
\hline County government bursary fund & 12 & $21.8 \%$ \\
\hline Households Financing through Fees payment & 55 & $100 \%$ \\
\hline Higher education loans board (HELB) & 11 & $20 \%$ \\
\hline Well Wishers / donors & 2 & $3.6 \%$ \\
\hline \multicolumn{2}{|c|}{ Source: Field Data (2019) } \\
\hline
\end{tabular}

Table 3 shows that all 55 Principals (100\%) indicated that National Government and households were the major sources of financing in the TVET institutions. Household financing was reported in all the sampled institutions and is normally in the form of fees payment and payment of other levies.

These levies mostly support institutional resource development. 2 principals (3.6\%) also indicated that they receive financing from well-wishers / donors.41 principals representing $74.5 \%$ indicated that they received financing from constituency bursary fund compared to $12(21.8 \%)$ of the principals who indicated that they received funding from the County government bursary fund.11 $(20 \%)$ of the principals indicated they received funding from HELB.
This implies that TVET institutions might be getting more funding from constituency bursary fund than from county government. However it suffices to note that in the study majority of the respondents were from VTCs compared to those from TTIs and the IST. The discrepancy in the allocation of government funding is due to the fact that all students in TTIs and IST qualify for loans from HELB which is not available to students in VTCs, but students in VTCs have access to funds from constituency bursary fund and county bursary fund.

\section{Adequacy of Budget Received by TVET Institutions and student enrolment}

Principals were finally requested to indicate the level of adequacy of the finances received from the various agencies. Their responses are analyzed as shown in table 4 . 
Table-4: Adequacy of Budget Received by TVET Institutions

\begin{tabular}{|c|c|c|c|c|c|c|}
\hline Source of finding & $\begin{array}{l}\text { Not at } \\
\text { All }\end{array}$ & $\begin{array}{l}\text { Least } \\
\text { Adequate }\end{array}$ & $\begin{array}{l}\text { Moderately } \\
\text { adequate }\end{array}$ & Adequate & $\begin{array}{l}\text { Very } \\
\text { adequate }\end{array}$ & Mean \\
\hline & 1 & 2 & 3 & 4 & 5 & \\
\hline National Government & 1 & 33 & 11 & 10 & 0 & 2.55 \\
\hline County Government & 43 & 12 & 0 & 0 & 0 & 1.22 \\
\hline CDF Bursaries & 14 & 27 & 14 & 0 & 0 & 2.00 \\
\hline Scholarships & 55 & 0 & 0 & 0 & 0 & 1.00 \\
\hline $\begin{array}{l}\text { Well Wishers/ Donor } \\
\text { support }\end{array}$ & 53 & 2 & 0 & 0 & 0 & 1.04 \\
\hline HELB & 41 & 6 & 4 & 0 & 0 & 1.18 \\
\hline $\begin{array}{l}\text { Households through } \\
\text { Fees payment }\end{array}$ & 0 & 12 & 19 & 20 & 4 & 3.29 \\
\hline
\end{tabular}

The results in Table 4 show that $34(61.8 \%)$ of the respondents indicated that budgetary allocation by National Government was not adequate (score 1 and 2 on the scale) as compared to 21 representing $38.2 \%$ who indicated that the allocation was either moderately adequate or just adequate (scores 3 and 4 on the scale). With a weighted average of 2.55 , the results suggest that budgetary allocation to TVET institutions by National Government in Bungoma County was moderately adequate.

Budgetary allocation by Households through Fees payment had the highest mean of 3.29 which represents moderately adequate on the scale. This indicates much of the TVET Institutions' budget was financed through fees payment. Budgetary financing through CDF bursaries (mean=2.00) was regarded to be least adequate while budget financing by other agencies like County government (Mean=1.22) and HELB (mean=1.18), scholarships (mean=1.00), Well Wishers/ Donor support $($ mean=1.04) were considered not adequate at all. This implies that majority of the respondents indicated that funding from most of the sources was not adequate.
The findings in Table 4 concur with the Kenya Economic Survey 2019 [2] which found that though HELB loans were given to TVET students it was not adequate due to insufficient allocation from the Treasury [2]. Additionally the Sessional Paper No.1 of 2019 [2], states that only 4\% of the education budget goes to TVET and further confirms that the low budgetary allocation has continued to negatively affect TVET institutions.

On the basis of these findings it is necessary to expand the budgetary resource base to fund TVET institutions in Bungoma County including the need to engage in lawful income generating activities without losing focus on training.

\section{Statistics for Budget Adequacy Indices.}

The ratings for each respondent were summed up to obtain an index which measured the adequacy of budget received by each institution surveyed. The index ranged from 7 to 35 . An index of more than 21 could imply budget adequacy while an index of less than 21 could construe budgetary inadequacy. The descriptive statistics for performance are shown in the Table 5.

Table-5: Budget Adequacy Indices on student enrolment

\begin{tabular}{|l|l|l|l|l|l|}
\hline & N & Minimum & Maximum & Mean & Std. Deviation \\
\hline Budget Adequacy & 55 & 7.00 & 35.00 & 14.4869 & 2.78314 \\
\hline Valid N (list wise) & 55 & & & & \\
\hline
\end{tabular}

Source: Field Data

As shown in Table 5, the mean budget adequacy index was 14.4869 with a standard deviation 2.78314. In the range of 7 to 35 , the mean budget adequacy index is below the average of 21 . This implies that the overall budget adequacy to TVET institutions in Bungoma County could be regarded inadequate.

Sessional paper No.1 of 2019 [2] concurs with the results in Table 4.18 which posits that TVET accounts for about 5\% of the total education expenditure in the Education sector. In spite of the fact that TVET is considered a driver for economic growth and development, it's still grossly under funded by government and this low budget adequacy has continued to be a major constraint to the TVET sector a key driver for rapid industrialization as outlined in Vision 2030, Big four agenda. Other than government allocation, there has been effort by government to fund the TVET sector through Higher Education Loans Board to students, National and County government bursaries, though the support has been inadequate in Bungoma County due to the large number of those seeking help. To this end the government proposes empowering TVET institutions to engage in lawful income generating activities without losing focus on their core mandate. 
6. Pearson correlation coefficient of Budget Adequacy and student enrolment TVET Institutions Pearson correlation coefficient was used to measure the strength and direction between the independent variable budget adequacy and the dependent variable student enrolment. The results are presented in Table 6.

Table-6: Pearson correlation Analysis of Budget Adequacy and student enrolment

\begin{tabular}{|l|l|l|l|}
\hline & & Student Enrolment & Budget Adequacy \\
\hline Student Enrolment & Pearson Correlation & 1 & $.547^{* *}$ \\
\hline & Sig. (2-tailed) & & .000 \\
\hline & N & 55 & 55 \\
\hline Budget Adequacy & Pearson Correlation & $.547^{* *}$ & 1 \\
\hline & Sig. (2-tailed) & .000 & \\
\hline & N & 55 & 55 \\
\hline
\end{tabular}

Correlation is significant at the 0.01 level (2-tailed).

The results in Table 6 , show a significant positive correlation between budget adequacy and student enrolment in the TVET Institutions in Bungoma County ( $\mathrm{r}=0.547, \mathrm{p}=0.000)$. The Pearson correlation coefficient also indicates the strength of the relationship is moderately strong.

\section{Regression Analysis of the relationship between Budget Adequacy and student enrolment of TVET Institutions}

To establish the relationship between budget adequacy and student enrolment, a simple linear regression analysis was used. Linear regression models are used to show or predict the relationship between two variables. The dependent variable is the factor being predicted and the factor that is being used to predict the value of the dependent variable is the independent variable [14]. The regression model was of the form:

$$
\mathbf{Y}=\mathbf{a}+\mathbf{b X}+\boldsymbol{\epsilon}, \quad \boldsymbol{\epsilon} \sim \mathbf{N}(\mathbf{0}, \mathbf{1})
$$

Where, $\mathrm{Y}$ is the student enrolment; $\mathrm{X}$ is the adequacy of budgetary allocation, ' $\mathbf{a}$ ' is the constant of the regression equation, ' $\mathbf{b}$ ' is the regression coefficient and $\epsilon$ is the error component.

\section{Coefficient of determination}

To assess the amount of variation of student enrolment that can be explained by budget adequacy, the coefficient of determination $\left(\mathrm{R}^{2}\right)$ was used and the results are shown in table 7.

Table -7: Coefficient of Determination

\begin{tabular}{|l|l|l|l|l|}
\hline Model & R & R-Square & Adjusted R-Square & Std. Error of the Estimate \\
\hline 1 & .547 & .299 & .297 & 7.82416 \\
\hline
\end{tabular}

a. Predictor: Budget Adequacy b. Dependent Variable: Student Enrolment

The result in Table 7 shows that an R-squared value of 0.299 was obtained and indicated that budget adequacy explains $29.9 \%$ of the variation in student enrolment in TVET institutions. This implies that $70.1 \%$ of variation in enrolment in TVET institutions can be attributed to other causes other than budget adequacy.

Furthermore, the findings in Table 7 are supported by the argument of the human capital theory which states that development of human skills, talents, ability and knowledge through education is an investment. This means that there is an element of cost through budget adequacy by either government or other relevant stakeholders. The corollary for this is that the more expenses that go into education particularly TVET the output in terms of skills acquisition which result in increased productivity $[15,16]$.

\section{9. $\operatorname{ANOVA}^{\mathrm{a}}(\mathbf{F})$ test statistics for Budget adequacy and student enrolment}

In assessing whether the model can significantly predict student enrolment in TVET institutions, the F-Statistic from the ANOVA table was used and the results are presented in table 8 .

Table -8: ANOVA $^{\text {a }}(\mathrm{F})$ test statistics for Budget adequacy and student enrolment

\begin{tabular}{|l|l|l|l|l|l|l|}
\hline \multicolumn{2}{|l|}{ Model } & Sum of Squares & Df & Mean Square & F & Sig. \\
\hline \multirow{2}{*}{1} & Regression & 177.177 & 1 & 177.177 & 30.606 & $.000^{\mathrm{b}}$ \\
\cline { 2 - 7 } & Residual & 306.817 & 53 & 5.789 & & \\
\cline { 2 - 6 } & Total & 1465.500 & 54 & & & \\
\hline
\end{tabular}

Source: Field Data 2019 
The results in Table 8 of the ANOVA $(\mathrm{F})$ test statistics show that the independent variable (budget adequacy) can significantly predict the student enrolment among the TVET institutions in Bungoma County $\left(\mathrm{F}_{(1,54)}=30.606, \mathrm{p}<0.05\right)$.
10. T-test for the Regression Coefficients ${ }^{\mathrm{a}}$ for Budget adequacy and student enrolment

In assessing the significance of the regression coefficient, the t-test for the regression coefficients was used the results of the regression coefficients and test for significance are shown in table 9.

Table 9: Regression Coefficients ${ }^{\mathrm{a}}$ for budget adequacy and student enrolment

\begin{tabular}{|c|l|l|l|l|l|l|}
\hline \multirow{2}{*}{ Model } & Unstandardized Coefficients & Standardized Coefficients & T & \multirow{2}{*}{ Sig. } \\
\cline { 3 - 5 } \multicolumn{2}{|l|}{} & B & Std. Error & Beta & & \\
\hline \multirow{2}{*}{1} & (Constant) & 1.336 & .783 & & 4.259 & .000 \\
\cline { 2 - 7 } & BA & .792 & .098 & .547 & 8.072 & .000 \\
\hline \multicolumn{2}{|l|}{ a. Dependent Variable: Student Enrolment } \\
\hline
\end{tabular}

Based on the regression coefficients in Table 9, the regression model for the relationship between budget adequacy and student enrolment is;

$$
\mathbf{Y}=1.336+0.792 \mathbf{X}
$$

The regression model indicates a positive relationship between budget adequacy and student enrolment implying that the more adequate the budget, the higher the student enrolment in the TVET institutions.

\section{T-test for testing the Null Hypothesis between Budget Adequacy and Student Enrolment}

To test whether this relationship was statistically significant, the following hypothesis was tested using the t-test as shown in Table 9.

$\mathbf{H}_{\mathbf{0}} \quad$ There is no significant relationship between budget adequacy and student enrolment in TVET Institutions in Bungoma County.

$$
\text { i.e. }\left(\mathrm{H}_{0}: b=0 \text { vs } \mathrm{H}_{\mathrm{a}}: \mathrm{b} \neq 0\right)
$$

$\mathbf{H}_{\mathbf{a}} \quad$ There is a statistically significant relationship between budget adequacy and student enrolment in TVET Institutions in Bungoma County.

The results illustrated in table 9, show that the t-test values for the budget adequacy coefficient is significant at 0.05 level of significance $(t=8.072, \mathrm{p}<$ $0.05)$. On the basis of these results, the null hypothesis stands rejected and the alternative hypothesis is accepted, which states that budget adequacy is statistically significant to student enrolment at 0.05 level of significance, likewise, the constant of the regression model is significant at 0.05 level of significance $(\mathrm{t}=4.259, \mathrm{p}<0.05)$.

Further the findings illustrated in Table 9 concur with Mutiso et al., [6] who found that adequate government capitation, tuition and other money sources were found to be of significant importance for accessing standard education of the institution. Although Mutiso et al., [16] supported the current study; their findings were limited to superior higher education in Kenyan public universities. The researcher was therefore sceptical in generalizing the results to TVET institutions in Kenya. Additionally the findings in Table 4.22 support the arguments of the Human Capital Theory which posit that at the bedrock of the theory is the believe that education including TVET is an investment that brings return to a person in particular and to the Nation or State in general.

This probably implies that budget adequacy to TVET is an investment that brings return on investment to an individual and the Nation or County at large when enrolment to TVETs increases. The researcher posits that with increased budget adequacy for institutional resource development such as infrastructure development, capacity building of instructors and trainers, provision of teaching/ learning equipment from different sources, such as government capitation, tuition, CDF, HELB, County government among others, student enrolment will be increased in TVET institution.

\section{CONCLUSION}

The study sought to investigate the relationship of budget adequacy in TVET and student enrolment in TVET institutions Bungoma County. The study established that the TVET institutions were not adequately equipped with important institutional resources such as workshops, laboratories, teaching/ learning equipment and instructors hence the need for more funding. On the source of funding the study established that the National Government and households were the major sources of financing in the TVET institutions. Household financing was reported in all the sampled institutions and is normally in the form of fees payment and payment of other levies. The mean budget adequacy index of 14.4869 indicated that the overall budget adequacy in TVET institutions in Bungoma County was not adequate. The correlation analysis result showed a moderately strong significant positive relationship between budget adequacy and student enrolment in the TVET Institutions in Bungoma County $(\mathrm{r}=0.547, \mathrm{p}=0.000)$. The $\mathrm{R}$-squared value of 0.299 indicated that budget adequacy explains $29.9 \%$ of the variation in student enrolment in TVET institutions while the t-test values for the budget adequacy 
coefficient was significant at 0.05 level of significance $(\mathrm{t}=8.072, \mathrm{p}<0.05)$. The study also concluded that budget adequacy in TVET institutions has a significant relationship with the overall enrolment of students in the TVET institutions.

\section{POLICY RECOMMENDATIONS}

i. On budget adequacy, the study recommended that government makes adequate budget allocation to TVET institutions for institutional resource development in order to increase student enrolment.

ii. Secondly TVET institutions should be empowered to engage in income generating activities without losing focus on their core mandate.

iii. Thirdly, donors/development partners can be encouraged to prioritize support to TVET institutions financially.

\section{REFERENCES}

1. UNESCO. (2013). Promoting learning for the world of work: What is TVET? . Retrieved March 10, 2013, from UNESCO: http://www.unevoc.unesco.org/go.php?q=more+ab out+What+is+TVETWonacott, M.E. 2001. Keeping vocational/career-technical educators current. Trends and Issues Alert, 23. www.calproonline.org/eric/docs/tia00091.pdf Retrieved 30 July 2015

2. RoK. (2019). Ministry of Education Sessional Paper No. 1 of 20190nA Policy Framework For Reforming Education And Training For Sustainable Development In Kenya Towards Realizing Quality, Relevant And Inclusive Education And Training For Sustainable DevelopmentPrinted By The Government Printer, Nairobi

3. European Training Foundation,. (2014). Evaluation Of The State Programme For TVET Development In Azerbaijan 2007-2012 Final Report. European Union.

4. Kipyego, M. A. (2016). Government subsidies and their influence on student access and retention in secondary schools in nandi north sub-county, kenya A Thesis Submitted to the School of PostGraduate Studies in Partial Fulfilment of the Requirements of the Degree of Masters of Education Management (Planning), Faculty of Education and Human Resource Development, Department of Education Management and Administration, Kisii University

5. Anyanwu, J., \& Erhijakpor, A. (2009). Education Expenditures and School Enrolment in Africa: Illustrations from Nigeria and Other SANE Countries.
6. Mutiso, J.M., Onyango, M., \& Michael Nyago, M. (2015). Effects of Funding Sources on Access to Quality Higher Education in Public Universities in Kenya: A Case Study. International SocioEconomic Research, USA. http://www.thejournalofbusiness.org/index.php/site

7. Rabia, T., Rabia, M., Vaqar, A., Junaid, Z., Waleed, I., \& Saleem, M. (2019). Intergratin Gender into Educational Planning and Budgeting. Working Paper \#17

8. Sarkar, S., Hossain, S., \& Rahman, R. (2014). "Budgetary provision for higher education: Evidence from Bangladesh", Journal of Public Budgeting, Accounting \& Financial Management, 26 (4), 643-671. https://doi.org/10.1108/JPBAFM26-04-2014-B005

9. Mutegi, R.G. (2015). Influence of Unit Cost of Education on Students Enrolment Rates inPublic Secondary Schools in Tharaka South Sub-county, Kenya. Published PhD thesis, University of Nairobi

10. Hemelt, S.W., \& Marcotte, D.E. (2011). The Impact of Tuition Increases on Enrollment at Public Colleges and Universities. Educational Evaluation and Policy Analysis, 33(4) (December 2011), pp. 435-457. American Educational Research Association.https://www.jstor.org/stable/41413066

11. Ivo, B., \& Ferry, P. (2015). "Determinants of local public expenditures on education: empirical evidence for Indonesian districts between 2005 and 2012," MAGKS Papers on Economics 201532, Philipps-Universität Marburg, Faculty of Business Administration and Economics, Department of Economics (Volkswirtschaftliche Abteilung).

12. Ali, E., Che'Rus, R., \& Abd Razak, M. R. (2018). The Relationship between Public Expenditure for Technical and Vocational Education and Employability Skills of the Graduates of Vocational Colleges in Malaysia. International journal of academic research in business and social sciences, $8(8)$.

13. Alecke, B., Mitze, T., \& Untiedt, G. (2013). Growth effects of regional policy in Germany: results from a spatially augmented multiplicative interaction model. The Annals of regional science, 50(2), 535-554.

14. Anderson, R. M., Heesterbeek, H., Klinkenberg, D., \& Hollingsworth, T. D. (2020). How will country-based mitigation measures influence the course of the COVID-19 epidemic?. The Lancet, 395(10228), 931-934.

15. Mincer, J. (1958). Investment in human capital and personal income distribution. Journal of political economy, 66(4), 281-302.

16. Becker, G. S. (1993). Nobel lecture: The economic way of looking at behavior. Journal of political economy, 101(3), 385-409. 